\title{
Utilization of Cable Screen Earthing Current for Detection and Location of Earth Faults in Medium Voltage Networks
}

\author{
Krzysztof Łowczowski $^{a, *}$, Józef Lorenc ${ }^{a}$, Magdalena Czerniak ${ }^{a}$, Józef Zawodniak ${ }^{b}$ \\ ${ }^{a}$ Poznań University of Technology, 3A Piotrowo St., Poznań, 60-965, Poland \\ ${ }^{b}$ Association of Polish Electrical Engineers, Gorzów Department, 9 Grobla St., Gorzów Wielkopolski, 66-400, Poland
}

Received: February 08, 2021. Revised: February 24, 2021. Accepted: March 04, 2021.

() 2021 The Authors. Published by Lviv Polytechnic National University.

\begin{abstract}
The paper presents issues related with detection and location of earth faults in medium voltage (MV) networks. Attention is paid on cable and cable-overhead lines. The criterion value - cable screen earthing current is presented. Afterwards, the method of utilization of the cable screen earthing current for detection and location of earth faults is described. The next part of the paper presents the results of simulation research for different variants of earth faults in cable and cable-overhead lines. The presented relations are the basis of the developed algorithm of detection and localization of earth faults. The presented considerations were confirmed by an experiment performed in the MV network.
\end{abstract}

Keywords: earth faults; medium voltage network; protection relay; earth fault location; cable screen.

\section{Introduction}

Identification and localization of disturbances is the research topic since the very beginning of electrical power system development. Despite of the passage of many years, the effectiveness of the earth fault detection is limited - it is estimated that the effectiveness is in range of $90-95 \%$, what necessitates further research in the field of earth fault detection. Each earth fault creates a risk of electrocution and increases risk of insulation failure because of the voltage rise under phase to earth fault conditions. Because of that every earth fault has to be successfully detected. Limited effectiveness of the earth fault detection is a particularly serious problem because earth faults account for approximately 70-80\% of disturbances in MV network e.g. 72\% in Portugal [1]. One can expect a few earth faults in cable lines per $100 \mathrm{~km}$ of lines and approximately 20 earth faults in overhead lines per $100 \mathrm{~km}$ over year.

Location of earth fault is a more severe problem. Among many solutions presented in the literature [3]-[8] only earth fault current indicators and switches in depth of the network - reclosers have been installed in distribution system networks on a larger scale. Unfortunately, the installation of measuring equipment and remote switches is connected with high investment costs and operational problems e.g. difficult installation or technical constraints, connected with the operation of additional devices, and problems with coordination of protection relays.

The paper presents a concept of earth fault protection, which is based on the measurement of the cable screen earthing current. It is proposed to use the current measurement to detect and locate earth faults in MV networks.

\section{Cable screen earthing current}

Typically, cable lines consist of 3 single-core cables laid in trefoil or flat formation. Cable screens of the cables are short-circuited at both sides of the cable lines and connected with earthing system, which aims to limit

*Corresponding author. Email address: krzysztof.lowczowski@put.poznan.pl

This paper should be cited as: K. Łowczowski, J. Lorenc, M. Czerniak, J. Zawodniak. Utilization of cable screen earthing current for detection and location of earth faults in medium voltage networks. Energy Engineering and Control Systems, 2021, Vol. 7, No. 1, pp. 17 - 25. https://doi.org/10.23939/jeecs2021.01.017 
overvoltages occurring in transient states and during normal operation to safe levels [9]. The scheme of earthing of the cable screen bonding is presented in Fig. 1

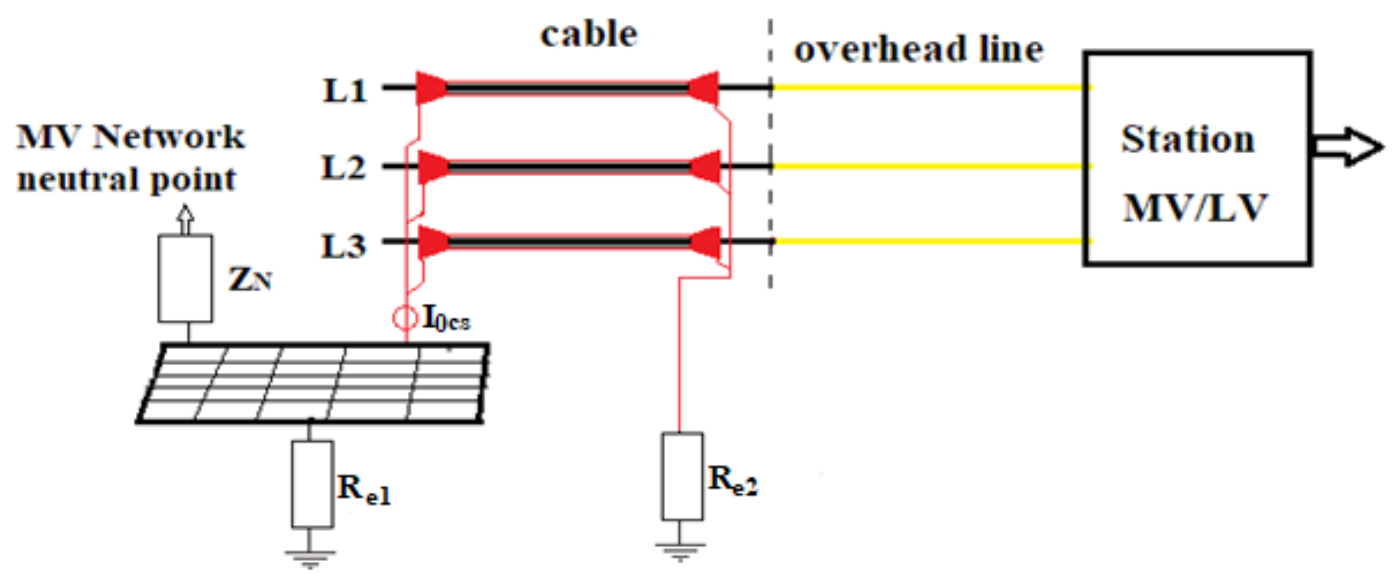

Fig. 1. Cable screen bonding $\left(I_{O c s}-\right.$ cable screen earthing current; $R_{e l}, R_{e 2}-$ earthing system resistance at both cable ends, $\mathrm{ZN}$ - impedance of the neutral point).

With some simplification, it can be assumed that in the event of an earth fault in the cable line, the cable screens and core are galvanically connected. Under these circumstances, the greater part of the current is flowing through the cable screens and returns to the neutral point of the earthing transformer. The smaller part of the current is flowing through earthing systems. The amount of current flowing through the earthing systems depend on earth system resistance, cable screen impedance and inductive coupling between cable screen and core.

In the case of earth fault in overhead section of the cable-overhead line, the great majority of earth fault current is flowing through earth, not the cable screen, because the earth resistance is about $\sim 0.05 \mathrm{ohm} / \mathrm{km}$, whereas the earthing system resistance is about a few ohms. Zero sequence current flowing through cable screens is the result of inductive coupling between cable core affected by earth fault, and cable screens.

Additionally, each earth fault, regardless of the place of its occurrence, causes the current flow in the cable core. The current flow is a result of the phase to earth capacitances. The capacitive current flows to the cable line from two sides, but due to the low resistance of the earth electrodes in the 110/15 substation in relation to the resistance of the earthing system at the load side, the big part of the capacitive cable screen current is flowing through earthing system at the side of $110 / 15$ substation.

One has to however underline, that cable screen earthing current may be a result of different sources, which are not directly connected with phase to earth fault. As is presented in [11], one can eliminate or greatly reduced the impact of the different sources using appropriate methods of signal filtering.

The case of earth fault in cable line can be presented using the equivalent circuit diagram shown in Fig.2.

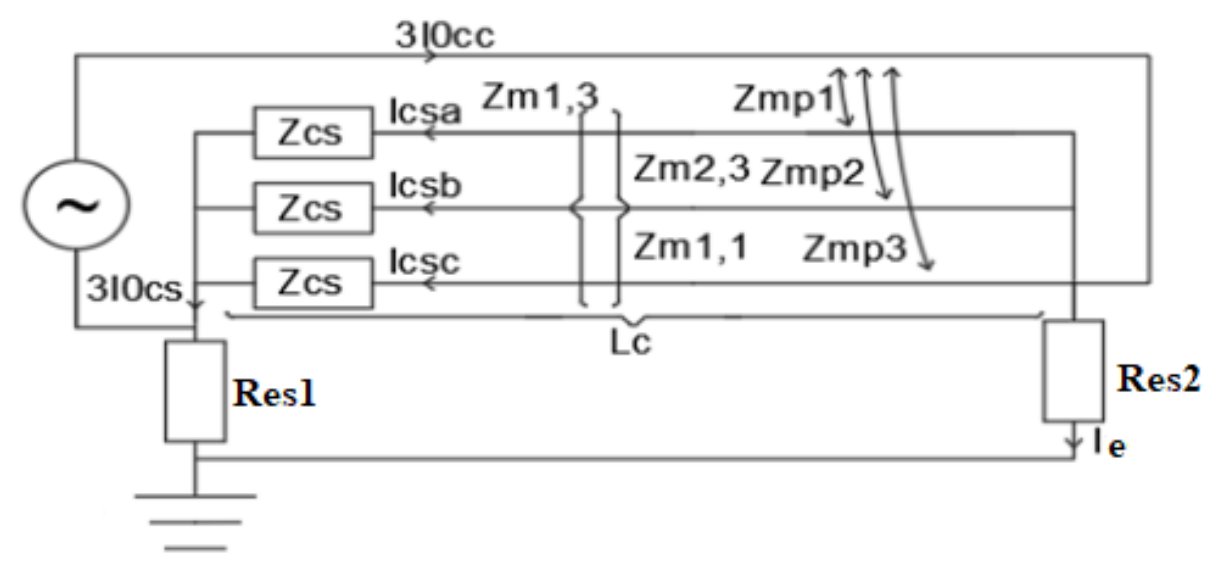

Fig. 2. Equivalent circuit of cable line under phase to earth fault conditions. 
The relations presented in Fig. 2. allow for the formulation of a set of equations describing the earth fault current flow in the cable line.

$$
\begin{gathered}
a_{11} I_{c s a}+a_{12} I_{c s b}+a_{13} I_{c s c}=b_{1} I_{0 c c}, \\
a_{22} I_{c s b}+a_{21} I_{c s a}+a_{23} I_{c s c}=b_{2} I_{0 c c}, \\
a_{33} I_{c s c}+a_{31} I_{c s a}+a_{32} I_{c s b}=b_{3} I_{0 c c}, \\
I_{g r}=3 I_{0 c c}-\left(I_{c s a}+I_{c s b}+I_{c s c}\right),
\end{gathered}
$$

where

$$
\begin{array}{cc}
a_{i i}=\left(R_{e s 1}+L_{c} z_{c}+R_{e s 2}\right) ; & i \in[1,3] \\
a_{i j}=\left(R_{e s 1}+L_{c} z_{m i, j}+R_{e s 2}\right) ; & i \neq j \\
b_{i}=\left(R_{e 1 s}+L_{c} z_{m p, i}+R_{e s 2}\right) ; & i \in[1,3]
\end{array}
$$

After solving the system of equations using the substitution method, one obtains the formula describing the value of the cable screen earthing current on the 110/15 substation side.

$$
3 I_{0 c s}=3 I_{0 c c}\left(1-\frac{3 R_{e s 1}+L_{c}\left(z_{c s}-z_{m p, 1}\right)}{L_{c}\left(z_{m 1,2}+z_{z}\right)+3 R_{e s 1}+3 R_{e s 2}}\right) .
$$

Analysis of the formula allow us to conclude, that cable screen current is a part of the cable core zero-sequence current. The complex numbers in the formula show that there is a phase shift between the zero sequence components of the currents. The phase shift depends on the parameters of the cable line.

Based on the formula (8), two criterion quantities are proposed - the $R F_{110 / 15}$ coefficient describing the ratio of the zero-sequence current in cable screens and cable cores, and the angle $\alpha$ - describing the phase shift between the zero-sequence current in cable screens and cable cores.

\section{Simulation results}

\subsection{General information}

In order to investigate the possibilities of using the proposed values $-R F_{110 / 15}$ and the angle $\alpha$ for the detection and location of earth faults, simulation research in PSCAD software was performed. The model consists of cable lines modeled using the library Cable System. The cable line under analysis are: 120/25, 150/25, 150/50 cable lines laid in trefoil formation. Attention was paid on cable length and earthing system resistance because of performed sensitivity analysis, the parameters have the biggest impact on earth fault current flow.

\subsection{Earth faults in cable line}

Fig. 3. presents the changes in a value of $R F_{110 / 15}$ under phase to earth fault conditions along the cable line. Cable lines with a length of 1,5 and $10 \mathrm{~km}$ were analyzed and the fault location was described as the relative length between the 110/15 substation and the fault location. The presented results allow to conclude that the values of $R F_{110 / 15}$ decrease with increasing distance of the fault location from the $110 / \mathrm{MV}$ station, which can be used to initially determine the fault location in the cable line, and therefore shorten the repair time. In order to increase the accuracy of the fault location, it is advisable to use an additional value - angle $\alpha$, which increases with the distance to the fault location - Fig. 4. 


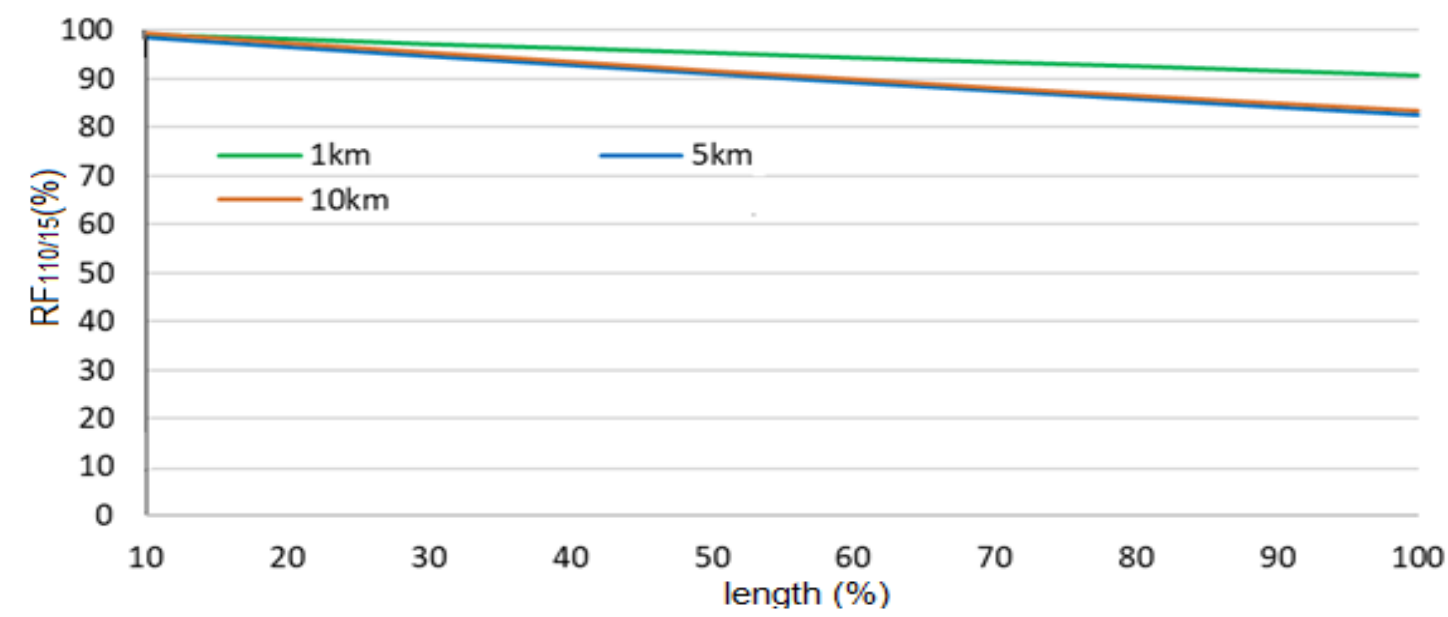

Fig. 3. $R F_{110 / 15}$ as a function of fault location in $120 / 25$ cable line $\left(R_{e s}=\right.$ const $\left.=2 \Omega\right)$.

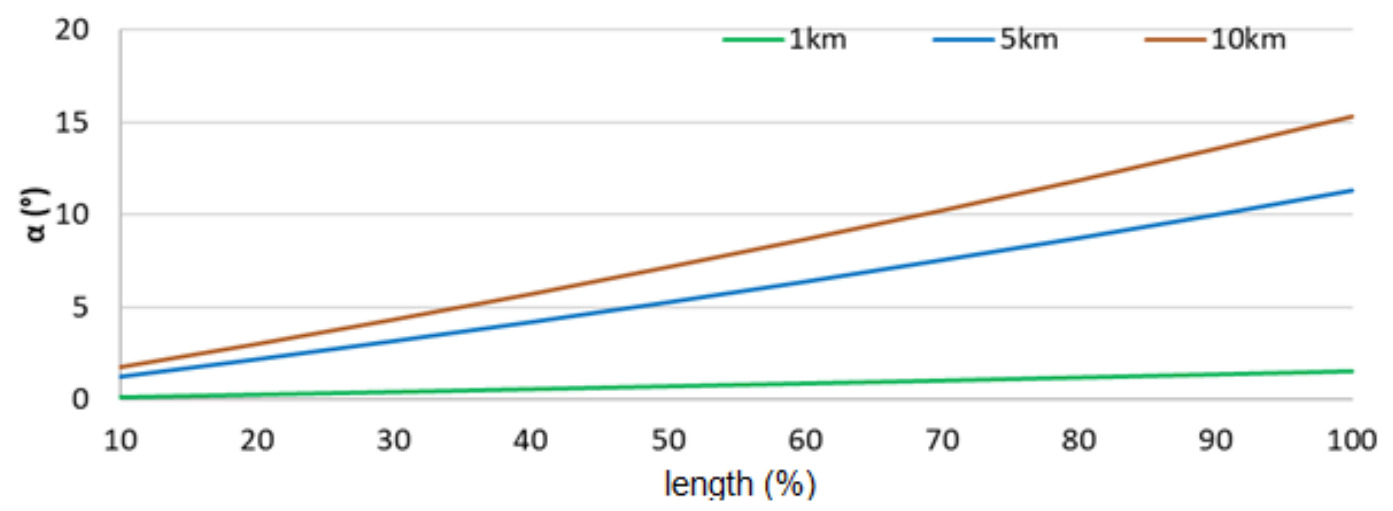

Fig. 4. The angle $\alpha$ as a function of fault location in $120 / 25$ cable line $\left(R_{e s}=\right.$ const $\left.=2 \Omega\right)$.

\subsection{Earth faults in overhead section of cable-overhead line}

In the next part of the research, waveforms of electrical quantities under earth fault conditions in cable line, which is a part of mixed - cable overhead line are analyzed. Attention is paid on $R F_{110 / 15}$ and angle $\alpha$. In the next part of the research, waveforms of electrical quantities under earth fault conditions in cable line, which is a part of mixed cable overhead line are analyzed. Attention is paid on $R F_{110 / 15}$ and angle $\alpha$.

Based on the research result, presented in Fig. 5 and Fig. 6 one can simply conclude, that a value of $R F_{110 / 15}$ is rising with the rise of cable length, what is a result of inductive coupling between cable core, in which the earth fault current is flowing, and cable screens. The induced voltage depends on cable length whereas the current is limited by earthing system resistance, which is held constant during simulations. At the same time, the angle $\alpha$ decreases because the ratio of the amount of power dissipated on the earthing system resistance and the total source power increases with the rise of the length of the cable line. One can clearly state, that both $R F_{110 / 15}$ and the angle $\alpha$ strongly depend on the length of the cable line and the resistance of the earthing system resistance. 


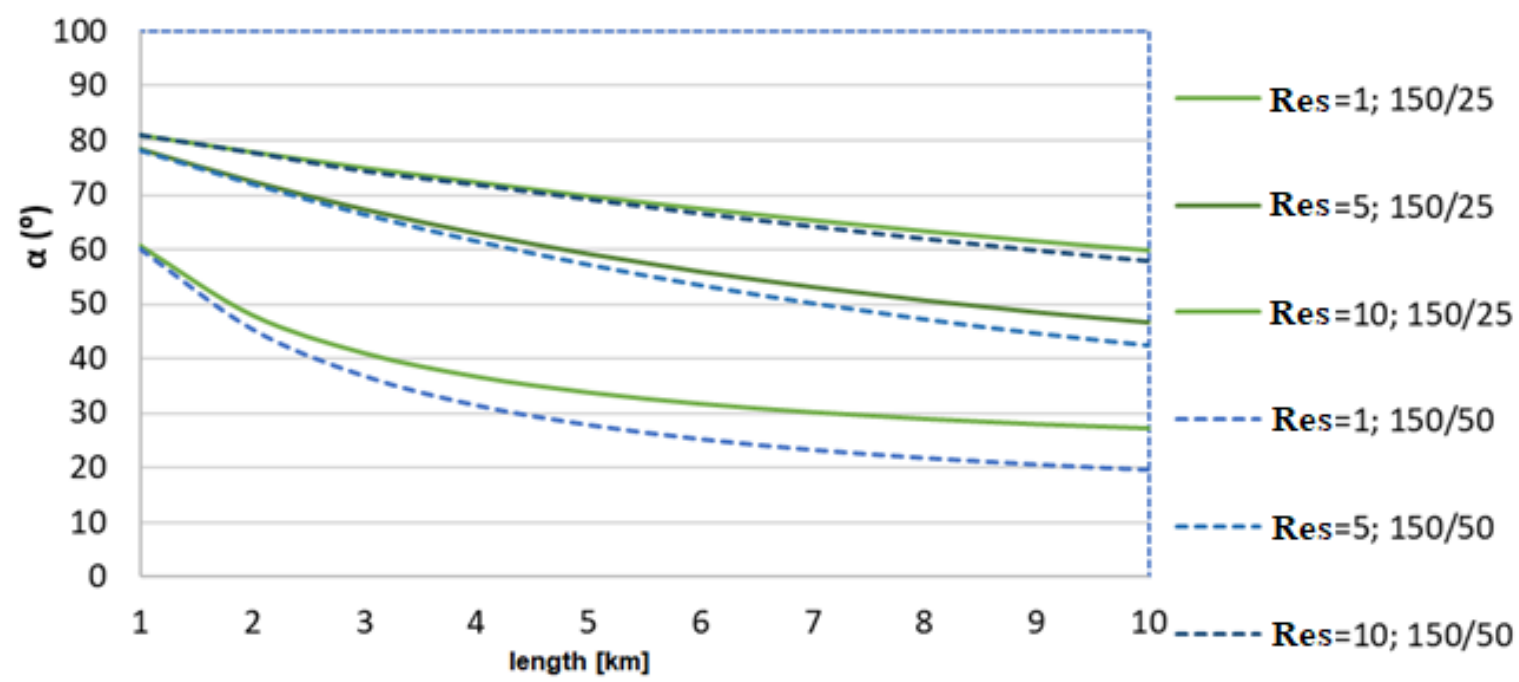

Fig. 5. The angle $\alpha$ as a function of cable length and earthing resistance under phase to earth fault conditions in the overhead section of the cable-overhead line.

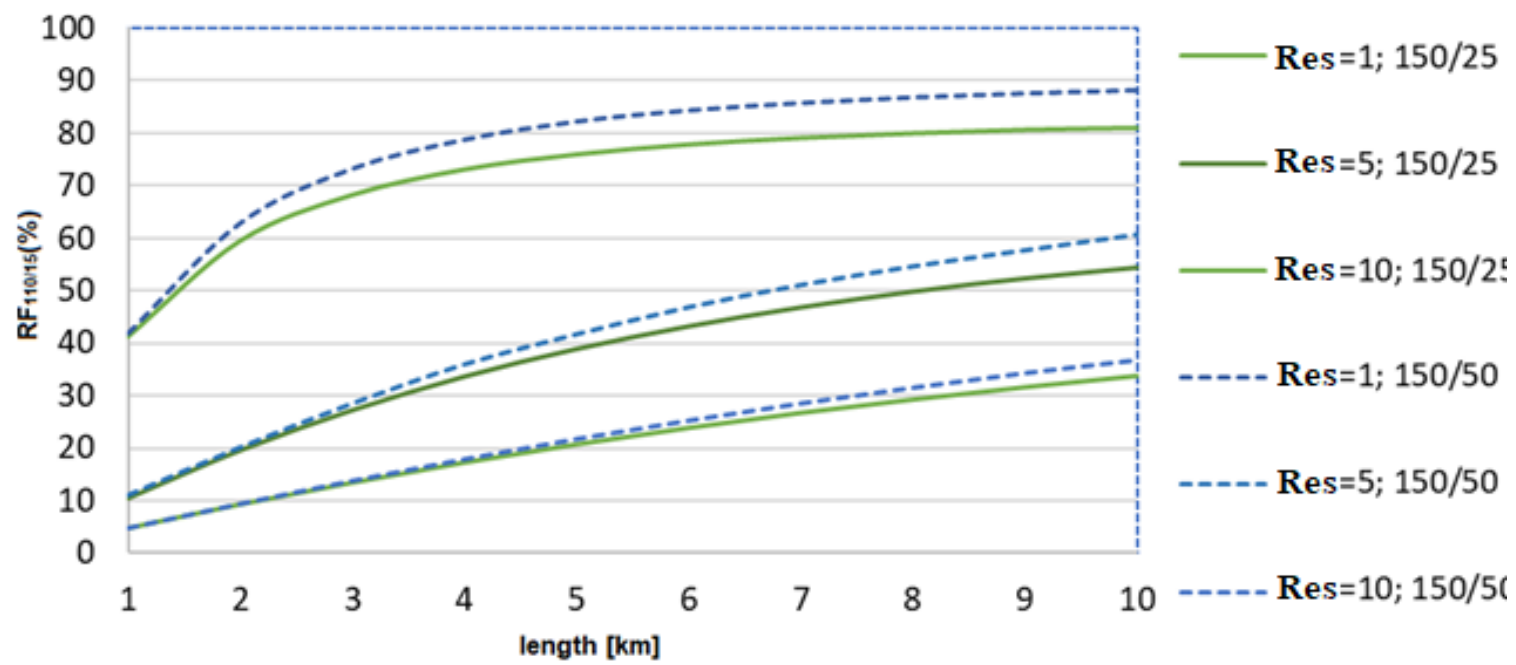

Fig. 6. $R F_{110 / 15}$ a function of cable length and earthing resistance under phase to earth fault conditions in the overhead section of the cable-overhead line.

Next figures -7 and 8 presented a case of earth faults at the end of the cable line because, as is shown earlier (Fig. 3 and Fig. 4), earth faults at the end of the cable line are characterized by the smallest value of $R F_{110 / 15}$ and the biggest value of angle $\alpha$. Therefore the faults at the end of the cable line have the greatest similarity to faults in the overhead section. As can be noticed in Fig. 7, the $R F_{110 / 15}$ for earth faults in cable line is in the range of 80-100\%. The high value of $R F_{110 / 15}$ is a result of 2 sources of earthing current - galvanic connection and inductive coupling. The earthing current resulting from galvanic connection, measured at the side of 110/15 substation, decreases with the rise of cable length because a growing part of the current is returning to the substation neutral point through the earthing system at the load side. At the same time, when the current resulting from galvanic connection is decreasing, the current resulting from inductive coupling is rising. 


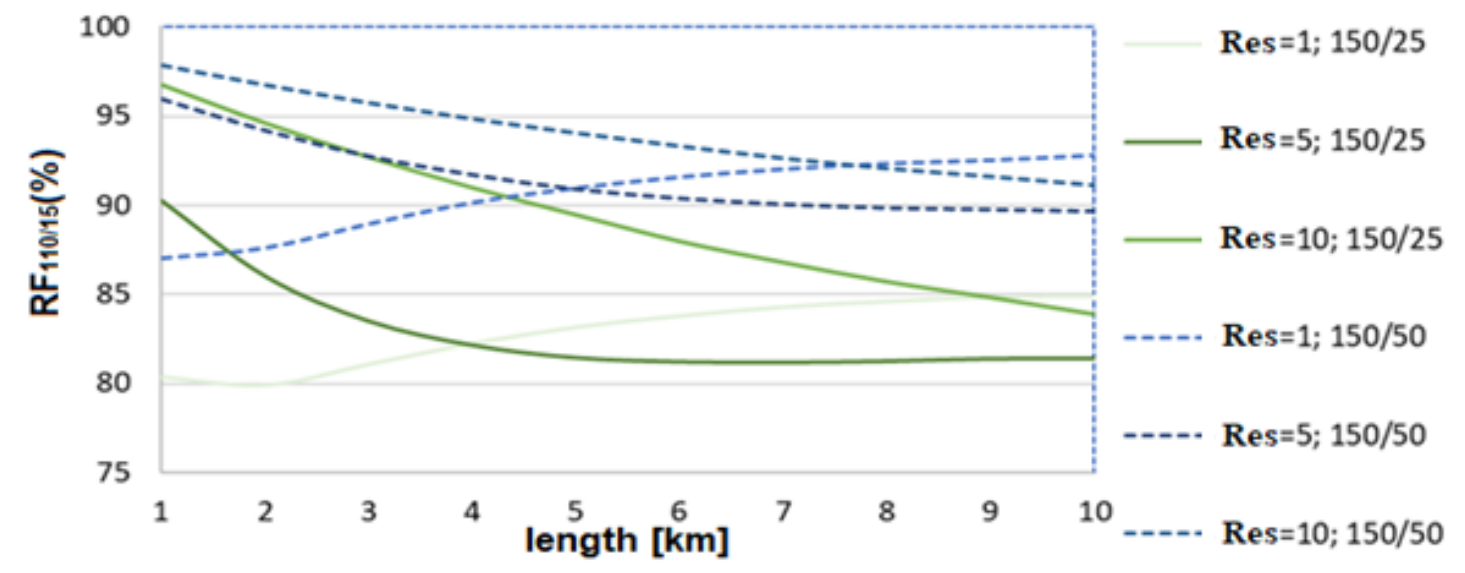

Fig. 7. $R F_{110 / 15}$ a function of cable length and earthing resistance under phase to earth fault conditions in the overhead section of the cable-overhead line.

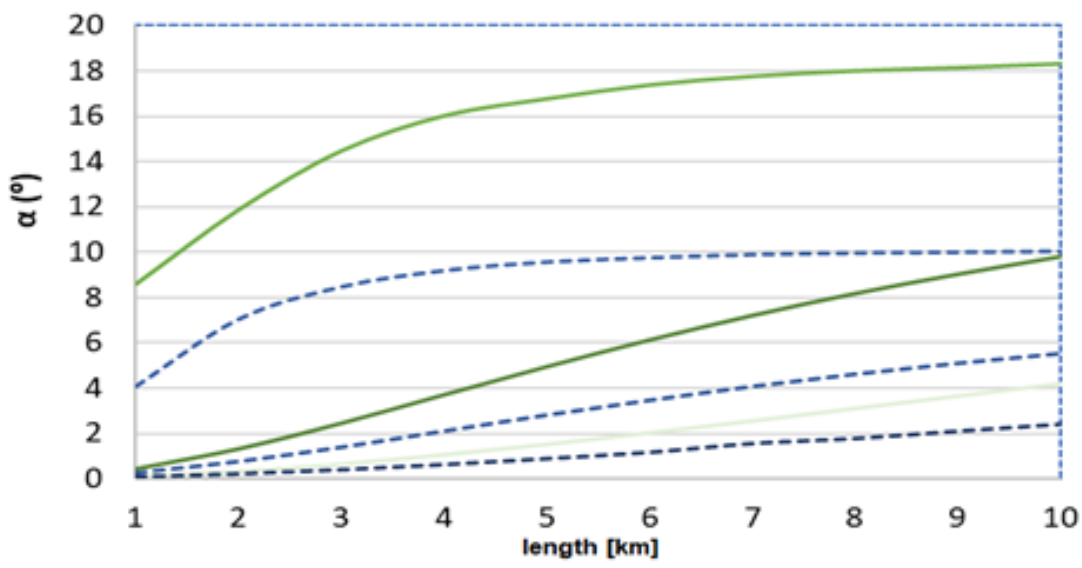

Res $=1 ; 150 / 25$

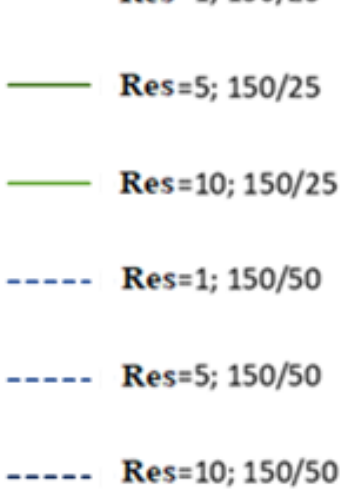

Fig.8. The angle $\alpha$ as a function of cable length and earthing resistance under phase to earth fault conditions in the overhead section of the cable-overhead line.

\section{Earth fault protection algorithm}

Simulation results presented above allow us to notice, that based on $R F_{110 / 15}$ and $\alpha$, it is possible to identify line type under phase to earth fault conditions. In order to improve the readability of results, the $R F_{110 / 15}$ is combined with angle $\alpha$, as a result, a function $R F_{110 / 15}=f(\alpha)$ is obtained - Fig. 9. As can be seen, comparators can be used to identify if earth fault parameters lay in the area of the cable or overhead earth faults.

In order to detect and identify line type under earth fault conditions, the protection algorithm was developed Fig. 10. The algorithm starts with processing the input quantities - filtration of $I_{0 c s}$ and $U_{0}$ (removing harmonics) and removing of the background. Background removal is based on the process of subtraction - the $I_{e s}$ after identification of earth fault is subtracted from $I_{e}$ before the earth fault occurrence. The subtraction is made in relation to $U_{0}$, which is artificially extended to the moment before the earth fault. The angle $\alpha$ is obtained based on the measured currents $I_{0 c s}$ and $I_{0 c c}$, further, the $\alpha$ is compared with the set $\alpha$ (yellow block) in order to identify the line type affected with the earth fault. Then, in parallel, the admittance values are determined as ratio of the currents $I_{0 c c}$ and $I_{O c s}$ and the voltage $U_{0}$ (green blocks in Fig. 10). The calculated values of $Y_{O c c}$ and $Y_{O c s}$ are compared with the corresponding settings (yellow blocks) in order to identify the line type affected with the earth fault. If an earth fault in a cable line is detected, the short time setting is used because the cable is permanently damaged, whereas in the case of earth faults in the overhead section one can use longer time settings because there is a relatively big probability that the reason of earth fault is temporary and the fault will disappear. 


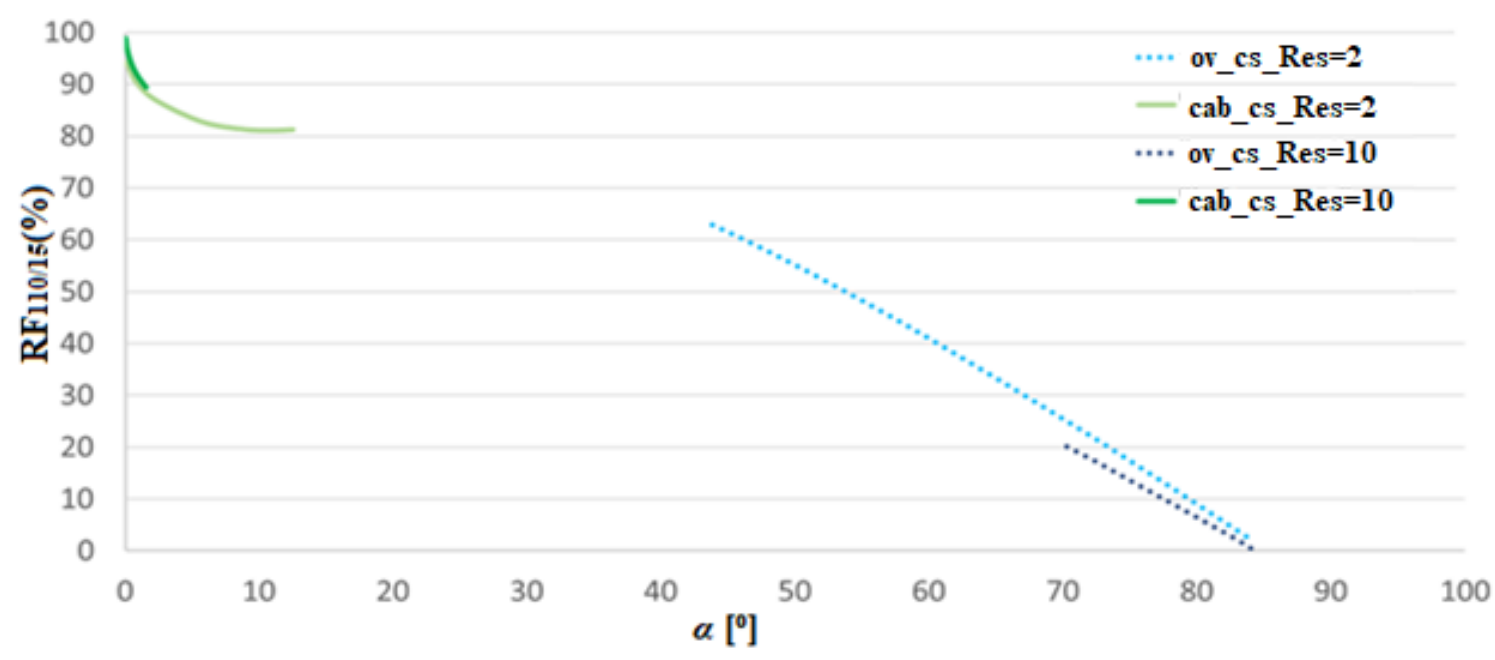

Fig.9. $R F_{110 / 15}$ as a function of angle $\alpha$.

Moreover, identification of line type allows blocking the auto-reclose relays in case of earth fault in cable line. The algorithm considers the measuring error of Ferranti transformers, which can be as high as $20 \%$ in unloaded lines, what practically eliminates the possibility of effective utilization of $I_{0 c c}$ [12]. If unfavorable conditions for Ferranti filter are identified, the algorithm block utilization of $I_{0 c s}$ and the earth fault is detected solely based on the modification of conventional admittance protection relay - $Y_{0 c s}$, which is calculated as $\left(I_{0 c s} / U_{0}\right)$ [13]. If the earth fault persists for a set time, the circuit breaker is opened.

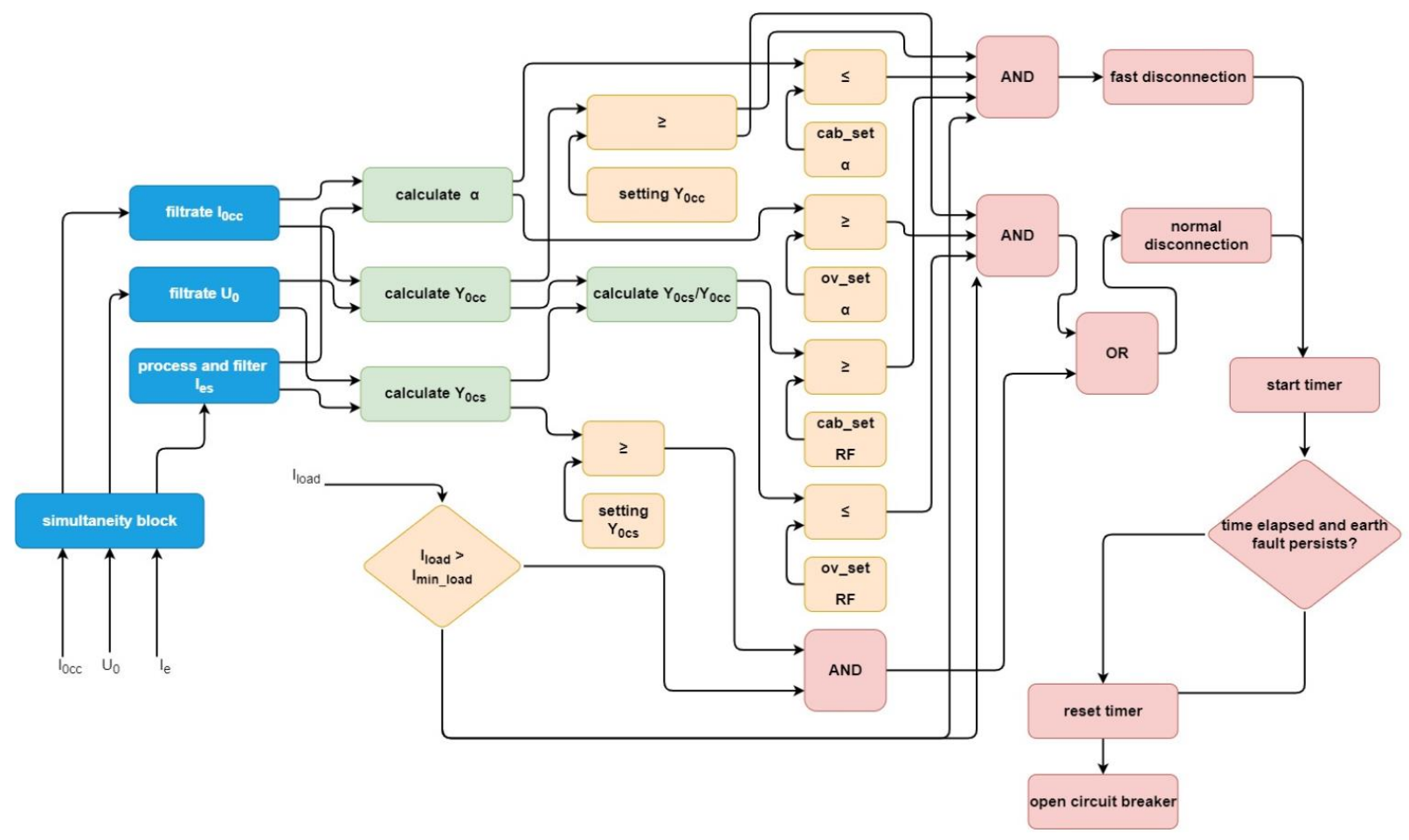

Fig.10. The developed protection algorithm.

\section{Network experiment}

In order to verify the correctness of the simulation results, a network experiment is carried out in the actual MV distribution network with the neutral point earthed by the Petersen coil $\left(Z_{N}=j \omega L\right)$ with a compensation degree in the range of 1.1 - 1.2. With the help of employees of the distribution system operator, a cable-overhead line, in which 
earth faults were made, was selected. Currents flowing through cable cores and screens, as well as zero-sequence voltage that occurred during the experiment, were recorded. A simplified diagram of the test system is shown in Fig. 11 , the tested cable line is marked in red and the overhead line is marked in yellow.

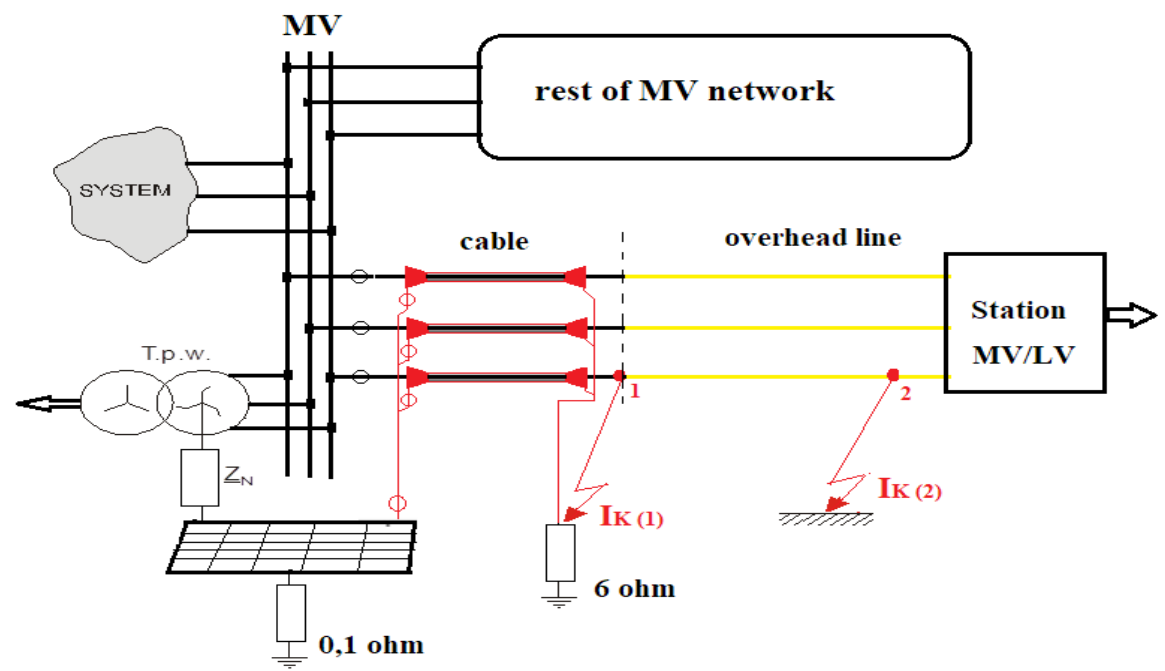

Fig.11. Scheme of the measurement system during network experiments T.p.w - auxiliary transformer (earthing), 1 - the earth faults in the cable line, 2 - the earth faults in overhead line, $\theta$ - places of recorded currents in the cables core, $\theta$ - places of recorded currents in the screen cables and in their earthing circuit.

Table 1 presents measurement and simulation results. Different cable screen bonding methods were analyzed and it was confirmed that simulation results are consistent with the measurement results. Moreover, simulation errors are small. Results presented in Table 1 confirm the possibility of using the developed algorithms in engineering practice.

Table 1. Characteristics of individual network experiments.

\begin{tabular}{|c|c|c|c|c|c|c|c|c|c|c|c|c|c|}
\hline \multirow[t]{2}{*}{ No. } & \multicolumn{4}{|c|}{ Measurements in the MV network } & \multicolumn{3}{|c|}{$\begin{array}{l}\text { Connection of } \\
\text { cable screen to } \\
\text { the ground* }\end{array}$} & \multicolumn{3}{|c|}{ Simulation research } & \multicolumn{3}{|c|}{ Simulation errors } \\
\hline & $I_{O c c}$ & $I_{0 c s}$ & $\alpha_{m}$ & $R F_{110 / 15-m}$ & A & B & $\mathrm{C}$ & $I_{0 c s}$ & $\alpha_{s}$ & $R F_{110 / 15-s}$ & $\begin{array}{c}\delta R F_{110 / 15} \\
{[\%]}\end{array}$ & $\begin{array}{c}\Delta R F_{110 / 15} \\
{[-]}\end{array}$ & $\begin{array}{c}\delta \alpha \\
{[\%]}\end{array}$ \\
\hline 1 & 44.03 & 42.71 & 1.75 & 97 & 1 & 1 & 1 & 43.38 & 0.03 & 98.5 & 1.59 & -0.68 & -1.91 \\
\hline $2 \mathrm{a}$ & 44.07 & 41.81 & 1.62 & 94.9 & 1 & 0 & 1 & 43.13 & 0.14 & 97.9 & 3.12 & -1.31 & -1.64 \\
\hline $2 b$ & 42.67 & 40.21 & 2.7 & 94.2 & 1 & 0 & 1 & 41.76 & 0.14 & 97.9 & 3.89 & -1.55 & -2.84 \\
\hline $3 a$ & 34.87 & 33.35 & 1.98 & 95.6 & 0 & 0 & 1 & 33.40 & 0.29 & 95.8 & 0.21 & -0.05 & -1.88 \\
\hline $3 b$ & 33.39 & 31.28 & 1.44 & 93.7 & 0 & 0 & 1 & 31.99 & 0.29 & 95.8 & 2.25 & -0.71 & -1.28 \\
\hline $4 a$ & 33.40 & 31.02 & 3.35 & $\begin{array}{l}92.9 \\
\end{array}$ & 0 & 1 & 1 & 31.17 & 0.04 & 93.3 & 0.44 & -0.15 & -3.68 \\
\hline $4 \mathrm{~b}$ & 31.81 & 29.63 & 2.79 & 93.1 & 0 & 1 & 1 & 31.17 & 0.04 & 98 & 5.23 & -1.54 & -3.06 \\
\hline 5 & 31.60 & 0.68 & 86.9 & 2.14 & 1 & 1 & 1 & 0.89 & 81.84 & 2.8 & 31.75 & -0.21 & -5.62 \\
\hline
\end{tabular}

\section{Conclusion}

The developed algorithm is able to detect and locate earth faults using the cable screen earthing current and the zero-sequence voltage. The algorithm is also able to detect and locate earth faults based on relations between cable screen earthing current and zero sequence cable core current. In the proposed solution, the criterion values are $R F_{110 / 15}$ coefficient, which describes the ratio of the zero-sequence current in cable screens and zero-sequence current in cable cores, and the value of the phase shift between the zero-sequence current in cable screens and cable cores (angle $\alpha$ ). The utilization of the proposed values for earth fault detection allows to improve the efficiency of earth fault detection and to reduce the risk of unnecessary protection operation (unwanted tripping). The location tools allow to:

- define the approximate place of failure in the cable line, 
- define the type of line affected by the earth fault [14],

- indicate the line branches in which possibly the earth fault was occurred [15].

The correctness of the presented solutions is confirmed by the network experiment in the actual MV distribution network. The solution which is proposed can be operated as the independent earth fault protection algorithm or be operated as a complementary algorithm with the existing protection relays.

\title{
References
}

[1] ENERGY.2012.7.1.1 THEME (2012) Integration of Variable Distributed Resources in Distribution Networks.

[2] CIRED WG03 (1999) Fault Management in Electrical Distribution Systems.

[3] Linciks J., Baranovskis D. (2009) Single Phase Earth Fault Location in the Medium Voltage Distribution Networks. Scientific Proceeding of Riga Technical University, 25(25):13-18, doi: 10.2478/v10144-009-0002-6

[4] Farughian A., Kumpulainen L., Kauhaniemi K. (2019) Earth Fault Location Using Negative Sequence Currents. Energies, 12 , 3759. https://doi.org/10.3390/en12193759

[5] Jensena C.F., Nanayakkarab O.M.K.K., Rajapakseb A.D., Gudmundsdottira U.S., Bak C.L. (2014) Online fault location on AC cables in underground Transmission systems using sheath currents. Electric Power System Research, 115, 74-79, https://doi.org/10.1016/j.epsr.2014.04.002.

[6] Hoppel W., Sieluk W., Czarnecki D. (2019) Zabezpieczenie podimpedancyjne w terminalach polowych CZIP-PRO dla linii sredniego napięcia. Wiadomosci Elektrotechniczne, 87(6), 31-36, 10.15199/74.2019.6.6.

[7] Tutvedt Anders K., Sqguin R., Kjolle G., Simonsen S., Skoglund Hermansen T., Myhr I. (2017) Smart fault handling in medium-voltage distribution grid. 24th International Conference \& Exhibition on Electricity Distribution, Glasgow.

[8] Rajalakshmi B., Kalaivani L. (2015) Analysis of Partial Discharge in Underground Cable Joints. IEEE Sponsored 2nd International Conference on Innovations in Information Embedded and Communication Systems.

[9] IEEE Power Engineering Society (2003) IEEE Guide for Selection and Design of Aluminum Sheaths for Power Cables.: IEEE Std 635

[10] Moser A. (2014) Power System III - Faults and Stability in Power Systems. Lecture Notes, Aachen.

[11] Łowczowski K. (2020) Detection of Earth Faults in MV Cable Lines Using Electrical Quantities Measured in Cable Screens. Doctoral thesis, Poznań, Poland. (in Polish)

[12] Energotest (2015) The family of IO earth fault transformers. User manual. Gliwice, Poland. (in Polish)

[13] Lorenc J. (2007) Admittance earth-fault protection. Publishing House of Poznań University of Technology, Poznań, Poland. (in Polish)

[14] Łowczowski K., Lorenc J., Andruszkiewicz J., Nadolny Z., Zawodniak J. (2019) Novel Earth Fault Protection Algorithm Based on MV Cable Screen Zero Sequence Current Filter, Energies, 12, 3190. https://doi.org/10.3390/en12163190.

[15] Łowczowski K., Lorenc J., Zawodniak J., Dombek G. (2020) Detection and Location of Earth Fault in MV Feeders Using Screen Earthing Current Measurements. Energies, 13, 1293. https://doi.org/10.3390/en13051293.

\section{Використання струму заземлення екрану кабелю для виявлення та локалізації замикань на землю у мережах середньої напруги}

\author{
Кшиштоф Ловчовскі ${ }^{a}$, Юзеф Лоренц $^{a}$, Магдалена Черняк $^{a}$, Юзеф Заводняк ${ }^{b}$ \\ ${ }^{a}$ Познанська Політехніка, вул. Пьотрово 3А, Познань, 60-965, Польща \\ ${ }^{b}$ Асоціація польських електриків, Гожувське відділення, вул. Гробла 9, Гожув Вєлькопольскі, 66-400, Польщза
}

\section{Анотація}

У статті представлені питання, пов'язані з виявленням та локалізацією замикань на землю у мережах середньої напруги (СН). Приділено увагу кабельним та кабельно-повітряним лініям. Представлено значення критерію - струм заземлення екрану кабелю. Описано спосіб використання струму заземлення екрану кабелю для виявлення та локалізації замикань на землю. У наступній частині статті представлено результати імітаційних досліджень для різних варіантів замикань на землю в кабельних та кабельно-повітряних лініях. Представлені залежності є основою розробленого алгоритму виявлення та локалізації замикань на землю. Теоретичні розрахунки були підтверджені експериментом, проведеним у мережі СН.

Ключові слова: замикання на землю; мережа середньої напруги; реле захисту; місце замикання на землю; екран кабелю. 